\title{
PERBANDINGAN METODE SEPARABLE PROGRAMMING DAN QUADRATIC PROGRAMMING DALAM PEMECAHAN MASALAH PEMROGRAMAN NONLINIER
}

\author{
I Gede Wikan Adiwiguna $^{1 \S}$, G.K. Gandhiadi ${ }^{2}$, Ni Made Asih ${ }^{3}$ \\ ${ }^{1}$ Program Studi Matematika, Fakultas MIPA - Universitas Udayana [Email: wikanadiwiguna@gmail.com] \\ ${ }^{2}$ Program Studi Matematika, Fakultas MIPA - Universitas Udayana [Email: gandhiadi@unud.ac.id] \\ ${ }^{3}$ Program Studi Matematika, Fakultas MIPA - Universitas Udayana [Email: madeasih@unud.ac.id] \\ ${ }^{\S}$ Corresponding Author
}

\begin{abstract}
The Separable programming method solves nonlinear programming problems by transforming a nonlinear shape that consists of a single variable into a linear function and resolved by the simplex method. Meanwhile, the quadratic programming method accomplishes the two degrees nonlinear model by transforming the nonlinear shape into linear function with the Kuhn Tucker Conditions and resolved by the simplex Wolfe method. Both of these methods are applied to the Markowitz's portfolio model, which is to find the proportion of stock funds to obtain maximum profits by combination of three shares, such as BMRI, GGRM, and ICBP. The completion using the quadratic programming method is more effective and efficient with the same optimum value.
\end{abstract}

Keywords: Markowitz's portfolio, nonlinear programming, quadratic programming, separable programming

\section{PENDAHULUAN}

Pemecahan masalah optimasi dapat diselesaikan dengan pemrograman linier dan nonlinier. Semakin kompleksnya permasalahan yang ada di kehidupan nyata membuat pemecahan masalah optimasi seringkali merupakan masalah nonlinier, salah satunya seperti penelitian yang dilakukan oleh Insani (2017) yang membahas tentang optimasi tanaman pangan di kota Magelang dimana fungsi tujuan yang dibentuk merupakan fungsi nonlinier, sehingga diperlukan metode penyelesaian permasalahan pemrograman nonliner untuk memperoleh solusi optimumnya.

Metode untuk memperoleh solusi dari masalah nonlinier secara umum yaitu dengan pemecahan langsung (direct) atau tidak langsung (indirect algorithms) (Taha, 2007). Salah satu contoh metode langsung adalah metode pencarian langsung dan metode gradien. Pada metode pemecahan langsung letak titik optimum ditentukan dengan menyelidiki nilai fungsinya, titik yang memiliki nilai fungsi terbesar atau terkecil dibandingkan dengan nilai fungsi pada titik-titik yang lain maka itulah titik optimumnya. Sedangkan dalam metode tidak langsung, masalah asli digantikan dengan suatu alat bantu atau asumsi tambahan dalam menentukan nilai optimumnya, contohnya separable programming, quadratic programming, Karush Kuhn Tucker, chance constrained programming dan lainnya.

Separable programming merupakan metode yang dikembangkan oleh C.E Miller pada tahun 1963 yang memiliki asumsi bahwa semua fungsi tujuan dan kendalanya merupakan fungsi yang tiap sukunya hanya melibatkan variabel tunggal, sehingga fungsi tersebut dapat dipisahkan menjadi sejumlah fungsi yang hanya memuat satu variabel (Hillier \& Lieberman, 2005). Sedangkan, metode pemrograman kuadratik yaitu permasalahan pemrograman nonlinier dengan fungsi tujuan berupa fungsi kuadratik dan kendala berupa fungsi linier, sehingga perbedaan satu-satunya dengan pemrograman linier adalah fungsi tujuannya melibatkan pangkat dua dari variabel atau perkalian dari dua variabel.

Persamaan ide dari kedua metode ini adalah mentransformasikan fungsi tujuan yang merupakan fungsi nonlinier menjadi fungsi linier 
lalu diselesaikan dengan metode simpleks. Selain itu, solusi dari kedua metode ini bersifat taksiran (aproximation) karena sampai saat ini belum ada metode standar yang dapat menyelesaikan permasalahan nonlinier yang memiliki beragam bentuk dan teknik penyelesaian tersendiri, berbeda halnya dengan metode simpleks yang telah menjadi metode standar yang dapat memecahkan berbagai permasalahan pemrograman linier (Mulyono, 1989).

Berdasarkan latar belakang tersebut, maka tujuan penelitian ini adalah membandingan metode separable programming dan quadratic programming dalam pemecahan masalah pemrograman nonlinier dari aspek proses dan hasilnya untuk mengetahui bagaimana karakteristik dari kedua metode ini dalam menyelesaikan suatu permasalahan yang sama. Penerapan kedua metode ini menggunakan portofolio saham sebagai objek penelitian, yaitu mencari proporsi dana untuk memperoleh keuntungan maksimum dari kombinasi proporsi tiga saham menggunakan model portofolio Markowitz.

\section{METODE PENELITIAN}

Jenis data yang digunakan dalam penelitian ini adalah data sekunder yaitu data yang diperoleh tidak secara langsung dari objek penelitian melainkan diperoleh dari website www.investing.com. Data yang digunakan adalah data kuantitatif, yaitu data historis penutupan harga saham (closing price) mingguan perusahaan yang terdaftar di indeks LQ45 dengan teknik pengumpulan data untuk memilih ketiga saham tersebut menggunakan teknik studi dokumen.

Tahapan analisis data dengan metode separable programming dan quadratic programming sebagai berikut

1. Menghitung return dari masing-masing data historis harga saham (closing price) dengan persamaan berikut:

$$
\begin{aligned}
& R_{i t}=\ln \left(\frac{P_{i t}}{P_{i(t-1)}}\right) \\
& R_{i t} \quad=\text { Return saham ke- } i \text { pada } \\
& \text { periode ke- } t \\
& P_{i t} \quad=\text { Harga saham ke- } i \text { pada } \\
& \text { periode ke- } t \\
& P_{i(t-1)} \quad=\text { Harga saham ke- } i \text { pada } \\
& \text { periode ke- }(t-1)
\end{aligned}
$$

2. Menghitung expected return, varians dan kovarian dengan persamaan berikut:

$$
E\left(R_{i}\right)=\frac{\sum_{t=1}^{n} R_{i t}}{N}
$$

dengan,

$$
\begin{array}{lrl}
E\left(R_{i}\right) & = & \text { Expected return saham ke- } i \\
R_{i t} & = & \text { Return saham ke- } i \text { pada } \\
& \text { periode } t \\
N & & = \\
& \text { Banyaknya return } \\
& \sigma_{i}^{2}= & \frac{\sum_{t=1}^{n}\left(R_{i t}-E\left(R_{i}\right)\right)^{2}}{N}
\end{array}
$$

dengan,

$$
\begin{aligned}
& \sigma_{i}^{2}=\text { Risiko saham ke- } i \\
& E\left(R_{i}\right) \quad=\text { Expected return saham ke- } i \\
& N=\text { Banyaknya return } \\
& \sigma_{i j}=\frac{\sum_{i=1}^{n}\left(R_{i t}-E\left(R_{i}\right)\right)\left(R_{j t}-E\left(R_{j}\right)\right)}{N} \\
& \sigma_{i j} \quad=\text { Kovarian antara return } \\
& \text { saham } i \text { dan } j \\
& R_{i t} \quad=\text { Return saham ke- } i \text { pada } \\
& \text { periode } t \\
& E\left(R_{i}\right) \quad=\text { Expected return saham ke- } i \\
& R_{j t} \quad=\text { Return saham ke-j pada } \\
& \text { periode } t \\
& E\left(R_{j}\right) \quad=\text { Expected return saham ke- } j
\end{aligned}
$$

3. Membentuk model fungsi tujuan dan kendala berdasarkan model portofolio markowitz.

4. Menyelesaikan model fungsi tujuan dan kendala yang telah dibentuk dengan metode separable programming dan quadratic programming menjadi fungsi linier.

Langkah penyelesaian menggunakan metode separable programming sebagai berikut,

a. Membentuk fungsi separable.

Maksimumkan atau minimumkan

dengan kendala,

$$
z=\sum_{j=1}^{n} f_{j}\left(x_{j}\right)
$$

$$
\begin{gathered}
\sum_{j=1}^{n} g_{i j}\left(x_{j}\right)(\leq,=, \geq) b_{i}, \\
i=1,2, \ldots, m \\
x_{j} \geq 0, j=1,2, \ldots, n
\end{gathered}
$$

b. Menentukan banyaknya gridpoint $\left(x_{v j}\right)$.

c. Membentuk nilai fungsi gridpoint $f_{j}\left(x_{v j}\right)$ dan $g_{i j}\left(x_{v j}\right)$.

d. Membentuk fungsi tujuan dan kendala linier.

Maksimumkan atau minimumkan

$$
z=\sum_{j=1}^{n} \sum_{k=1}^{v} \lambda_{k j} f_{j}\left(x_{k j}\right)
$$


dengan kendala,

$\sum_{j=1}^{n} \sum_{k=1}^{v} g_{i j}\left(x_{k j}\right) \lambda_{k j}(\leq, \geq) b_{i}$,

$i=1,2, \ldots, m$

$\sum_{k=1}^{v} \lambda_{k j}=1, j=1,2, \ldots, n$

$\lambda_{k j} \geq 0$,

$k=1,2, \ldots, v$ dan $j=1,2, \ldots, n$

e. Menyelesaikan bentuk linier dengan metode simpleks.

Langkah penyelesaian menggunakan metode kuadratik sebagai berikut

a. Mengidentifikasi fungsi tujuan dan kendala ke dalam bentuk umum dari masalah pemrograman kuadratik.

Maksimumkan $\mathbf{z}=\mathbf{C X}+\mathbf{X}^{\mathbf{T}} \mathbf{D X}$

dengan kendala,

$$
\begin{gathered}
\mathbf{A X} \leq \mathbf{b}, \mathbf{X} \geq \mathbf{0} \\
\mathbf{X}=\left(x_{1}, x_{2}, \ldots, x_{n}\right)^{T} \\
\mathbf{C}=\left(c_{1}, c_{2}, \ldots, c_{n}\right) \\
\mathbf{D}=\left(\begin{array}{ccc}
d_{11} & \cdots & a_{1 n} \\
\vdots & \ddots & \vdots \\
d_{m 1} & \cdots & a_{n n}
\end{array}\right) \\
\mathbf{A}=\left(\begin{array}{ccc}
a_{11} & \cdots & a_{1 n} \\
\vdots & \ddots & \vdots \\
a_{m 1} & \cdots & a_{m n}
\end{array}\right) \\
\mathbf{b}=\left(b_{1}, b_{2}, \ldots, b_{n}\right)^{T}
\end{gathered}
$$

b. Membentuk model linier fungsi tujuan dan kendala menggunakan syarat Kuhn Tucker.

Aplikasi syarat Kuhn Tucker berdasarkan permasalahan kuadratik tersebut yaitu

$$
\begin{aligned}
& \lambda \geq \mathbf{0}, \mathbf{U} \geq \mathbf{0} \\
& \nabla \mathbf{z}-\left(\lambda^{T}, \mathbf{U}^{T}\right) \nabla \mathbf{G}(\mathbf{X})=\mathbf{0} \\
& \lambda_{i}\left(b_{i}-\sum_{j=1}^{n} a_{i j} x_{j}\right)=0 \text {, } \\
& i=1,2, \ldots, m \\
& \mu_{j} x_{j}=0, j=1,2, \ldots, n \\
& \mathbf{A X} \leq \mathbf{b} \\
& -\mathbf{X} \leq \mathbf{0}
\end{aligned}
$$

c. Mencari solusi optimal dengan melakukan proses iterasi simpleks metode wolfe.

Dalam perhitungan simpleks wolfe terdapat kondisi tambahan yang disebut dengan complementary slackness, yaitu

$\mu_{j} x_{j}=0=\lambda_{i} S_{i}$, untuk setiap $i \operatorname{dan} j$

\section{HASIL DAN PEMBAHASAN}

Objek penelitian pada studi kasus ini adalah data harga penutupan saham mingguan Bank Mandiri Tbk (BMRI) yang dinotasikan dengan $x_{1}$, Gudang Garam Tbk (GGRM) yang dinotasikan dengan $x_{2}$ dan Indofood CBP Sukses Makmur Tbk (ICBP) dinotasikan dengan $x_{3}$ periode 1 januari 2017 sampai 23 Desember 2018 yang diperoleh dari website www.investing.com. Sebelum melakukan perhitungan menggunakan metode separable programming dan quadratic programming terlebih dahulu dibentuk model nonlinier berdasarkan model portofolio markowitz dengan langkah-langkah sebagai berikut:

1. Menghitung return masing-masing saham menggunakan persamaan (1).

2. Menghitung expected return masingmasing saham menggunakan persamaan (2).

3. Menghitung risiko menggunakan persamaan (3) dan kovarian menggunakan persamaan (4).

Hasil perhitungan total return, expected return, varian dan kovarian disajikan dalam Tabel 1 dan Tabel 2.

Tabel 1. Total return, expected return dan varian.

\begin{tabular}{|c|l|c|c|c|}
\hline$i$ & Saham & $\begin{array}{c}\text { Total } \\
\text { Return }\end{array}$ & $\begin{array}{c}\text { Expected return } \\
\left(E\left(R_{i}\right)\right)\end{array}$ & $\begin{array}{c}\text { Varian } \\
\left(\sigma_{i}^{2}\right)\end{array}$ \\
\hline 1 & BMRI & 0,2590 & 0,00257 & 0,00146 \\
\hline 2 & GGRM & 0,2608 & 0,00258 & 0,00141 \\
\hline 3 & ICBP & 0,2036 & 0,00202 & 0,00077 \\
\hline
\end{tabular}

Tabel 2. Kovarian $\left(\sigma_{i j}\right)$

\begin{tabular}{|c|l|c|}
\hline No. & \multicolumn{1}{|c|}{ Saham } & Kovarian $\left(\sigma_{i j}\right)$ \\
\hline 1 & BMRI/GGRM & 0,000625 \\
\hline 2 & BMRI/ICBP & 0,000364 \\
\hline 3 & GGRM/ICBP & 0,000396 \\
\hline
\end{tabular}

\footnotetext{
Membentuk Model Nonlinier dari

Kombinasi Proporsi Tiga Saham

Berdasarkan Model Portofolio Markowitz.
} 
Expected return, varian dan kovarian yang diperoleh dari perhitungan sebelumnya disubstitusikan kedalam model portofolio Markowitz, yaitu

Maksimumkan,

$$
\begin{gathered}
f(x)=\sum_{i=1}^{3} x_{i} E\left(R_{i}\right)-\left(\sum_{i=1}^{3} x_{i}^{2} \sigma_{i}^{2}+\right. \\
\left.\sum_{i=1}^{3} \sum_{j=1}^{3} x_{i} x_{j} \sigma_{i j}\right), i \neq j
\end{gathered}
$$

dengan kendala,

$$
\begin{gathered}
\sum_{j=1}^{3} x_{j} \leq 1 \\
x_{j} \geq 0, \text { untuk } j=1,2,3 .
\end{gathered}
$$

Sehingga diperoleh model portofolio untuk mendapatkan keuntungan maksimum dengan cara memaksimalkan expected return pada tingkat risiko tertentu yaitu

Maksimumkan,

$$
\begin{aligned}
z= & 0,00257 x_{1}+0,00258 x_{2}+ \\
& 0,00202 x_{3}-\left(0,00146 x_{1}^{2}+\right. \\
& 0,00141 x_{2}^{2}+0,00077 x_{3}^{2}+ \\
& 0,00125 x_{1} x_{2}+0,000792 x_{1} x_{3}+ \\
& \left.0,000728 x_{2} x_{3}\right)
\end{aligned}
$$

dengan kendala,

$$
\begin{gathered}
\sum_{j=1}^{3} x_{j} \leq 1 \\
x_{j} \geq 0, \text { untuk } j=1,2,3 .
\end{gathered}
$$

\section{Penyelesaian Model Menggunakan Metode Separable programming}

Model yang telah diperoleh akan diselesaikan menggunakan metode separable programming dengan langkah-langkah sebagai berikut

1. Membentuk fungsi separable.

Model fungsi tujuan yang terbentuk pada persamaan (5) memiliki perkalian dua variabel sehingga perlu diubah kedalam bentuk fungsi yang hanya terdiri dari satu variabel dengan menggunakan manipulasi aljabar yaitu,

$$
x_{1} x_{2}=\frac{1}{2}\left(x_{1}+x_{2}\right)^{2}-\frac{1}{2} x_{1}^{2}-\frac{1}{2} x_{2}^{2}
$$

Misalkan $x_{1}+x_{2}=x_{4}$ diperoleh,

$$
x_{1} x_{2}=\frac{1}{2} x_{4}^{2}-\frac{1}{2} x_{1}^{2}-\frac{1}{2} x_{2}^{2}
$$

Dengan cara yang sama, maka

$$
x_{1} x_{3}=\frac{1}{2} x_{5}^{2}-\frac{1}{2} x_{1}^{2}-\frac{1}{2} x_{3}^{2} \text {, }
$$

dengan $x_{5}=x_{1}+x_{3}$ dan $x_{2} x_{3}=\frac{1}{2} x_{6}^{2}-\frac{1}{2} x_{2}^{2}-\frac{1}{2} x_{3}^{2}$, dengan $x_{6}=x_{2}+x_{3}$

Oleh karena itu, persamaan (5) dapat dituliskan sebagai berikut

$$
\begin{aligned}
z= & 0,00257 x_{1}+0,00258 x_{2}+ \\
& 0,00202 x_{3}-\left[0,000439 x_{1}^{2}+\right. \\
& 0,000421 x_{2}^{2}+0,00001 x_{3}^{2}+ \\
& 0,000625 x_{4}^{2}+0,000396 x_{5}^{2}+ \\
& \left.0,000364 x_{6}^{2}\right]
\end{aligned}
$$

Nilai $x_{1}+x_{2}=x_{4}, \quad x_{1}+x_{3}=x_{5}$ dan $x_{2}+x_{3}=x_{6} \quad$ yang diperoleh dari memanipulasi aljabar selanjutnya menjadi kendala baru, yaitu

$$
\begin{aligned}
& g_{1}(X)=x_{1}+x_{2}+x_{3} \leq 1 \\
& g_{2}(X)=x_{1}+x_{2}-x_{4}=0 \\
& g_{3}(X)=x_{1}+x_{3}-x_{5}=0 \\
& g_{4}(X)=x_{2}+x_{3}-x_{6}=0
\end{aligned}
$$

Sehingga fungsi separable yang dapat dibentuk berdasarkan fungsi tujuan dan kendala diatas adalah

$$
\begin{aligned}
& f_{1}\left(x_{1}\right)=0,00257 x_{1}-0,00044 x_{1}^{2}, \\
& f_{2}\left(x_{2}\right)=0,00258 x_{2}-0,0004 x_{2}^{2}, \\
& f_{3}\left(x_{3}\right)=0,002 x_{3}-0,00001 x_{3}^{2} \\
& f_{4}\left(x_{4}\right)=-0,000625 x_{4}^{2} \\
& f_{5}\left(x_{5}\right)=-0,000396 x_{5}^{2} \\
& f_{6}\left(x_{6}\right)=-0,000364 x_{6}^{2}
\end{aligned}
$$

dengan kendala,

$$
\begin{aligned}
& g_{11}\left(x_{1}\right)=x_{1}, \quad g_{12}\left(x_{2}\right)=x_{2}, \\
& g_{13}\left(x_{3}\right)=x_{3}, \\
& g_{21}\left(x_{1}\right)=x_{1}, g_{22}\left(x_{2}\right)=x_{2}, \\
& g_{24}\left(x_{4}\right)=-x_{4}, \\
& g_{31}\left(x_{1}\right)=x_{1}, g_{33}\left(x_{3}\right)=x_{3}, \\
& g_{35}\left(x_{5}\right)=-x_{5}, \\
& g_{42}\left(x_{2}\right)=x_{2}, g_{43}\left(x_{3}\right)=x_{3}, \\
& g_{46}\left(x_{6}\right)=-x_{6}
\end{aligned}
$$

$$
x_{1}, x_{2}, x_{3}, x_{4}, x_{5}, x_{6} \geq 0
$$

2. Menentukan banyaknya grid point.

Pada perhitungan ini akan digunakan 11 partisi $(v=1,2, \ldots, 11)$ pada interval $[0,1]$, yaitu $0 ; 0,1 ; 0,2 ; 0,3 ; 0,4 ; 0,5 ; 0,6 ; 0,7 ; 0,8 ; 0,9 ; 1$. Diperoleh nilai $x_{v j}$ untuk 11 partisi yaitu

Tabel 3. Titik Partisi Masing-Masing Variabel 


\begin{tabular}{|c|c|c|c|c|c|c|c|c|c|c|c|}
\hline \multirow{2}{*}{$j$} & \multicolumn{10}{|c|}{$x_{v}$} \\
\cline { 2 - 13 } & 1 & 2 & 3 & 4 & 5 & 6 & 7 & 8 & 9 & 10 & 11 \\
\hline 1 & 0 & 0,1 & 0,2 & 0,3 & 0,4 & 0,5 & 0,6 & 0,7 & 0,8 & 0,9 & 1 \\
\hline 2 & 0 & 0,1 & 0,2 & 0,3 & 0,4 & 0,5 & 0,6 & 0,7 & 0,8 & 0,9 & 1 \\
\hline 3 & 0 & 0,1 & 0,2 & 0,3 & 0,4 & 0,5 & 0,6 & 0,7 & 0,8 & 0,9 & 1 \\
\hline 4 & 0 & 0,1 & 0,2 & 0,3 & 0,4 & 0,5 & 0,6 & 0,7 & 0,8 & 0,9 & 1 \\
\hline 5 & 0 & 0,1 & 0,2 & 0,3 & 0,4 & 0,5 & 0,6 & 0,7 & 0,8 & 0,9 & 1 \\
\hline 6 & 0 & 0,1 & 0,2 & 0,3 & 0,4 & 0,5 & 0,6 & 0,7 & 0,8 & 0,9 & 1 \\
\hline
\end{tabular}

Titik partisi ini selanjutnya disubstitusikan ke persamaan (9) dan (10) untuk memperoleh konstanta baru dari fungsi linier yang akan dibentuk.

3. Membentuk nilai fungsi grid point

Titik-titik partisi $x_{v j}$ yang telah dibentuk selanjutnya disubstitusikan ke persamaan (9) dan (10) untuk memperoleh nilai $f_{j}\left(x_{v j}\right)$ dan $g_{i j}\left(x_{v j}\right)$ yang merupakan konstanta baru untuk fungsi liniernya.

4. Membentuk fungsi tujuan linier

Nilai $f_{j}\left(x_{v j}\right)$ dan $g_{i j}\left(x_{v j}\right)$ yang telah diperoleh selanjutnya disubstitusikan ke persamaan berikut

$$
z=\sum_{j=1}^{6} \sum_{k=1}^{11} \lambda_{k j} f_{j}\left(x_{k j}\right)
$$

dengan kendala,

$$
\begin{gathered}
\sum_{j=1}^{6} \sum_{k=1}^{11} g_{i j}\left(x_{k j}\right) \lambda_{k j}(\leq, \geq) b_{i}, \\
i=1,2,3,4 .
\end{gathered}
$$

Sehingga diperoleh fungsi tujuan dan kendala yang baru sebagai berikut

$$
\begin{aligned}
Z= & {\left[0 \lambda_{11}+0,00025 \lambda_{21}+0,00050 \lambda_{31}+\right.} \\
& 0,00074 \lambda_{41}+0,00097 \lambda_{51}+ \\
& 0,0012 \lambda_{61}+0,00142 \lambda_{71}+ \\
& 0,00163 \lambda_{81}+0,00183 \lambda_{91}+ \\
& \left.0,00203 \lambda_{101}+0,00222 \lambda_{111}\right]+ \\
& {\left[0 \lambda_{12}+0,00025 \lambda_{22}+0,0005 \lambda_{32}+\right.} \\
& 0,00074 \lambda_{42}+0,00096 \lambda_{52}+ \\
& 0,00118 \lambda_{62}+0,0014 \lambda_{72}+ \\
& 0,0016 \lambda_{82}+0,00179 \lambda_{92}+ \\
& \left.0,00198 \lambda_{102}+0,00216 \lambda_{112}\right]+ \\
& {\left[0 \lambda_{13}+0,0002 \lambda_{23}+0,0004 \lambda_{33}+\right.} \\
& 0,00061 \lambda_{43}+0,00081 \lambda_{53}+ \\
& 0,00101 \lambda_{63}+0,00121 \lambda_{73}+ \\
& 0,00141 \lambda_{83}+0,00161 \lambda_{93}+ \\
& \left.0,00181 \lambda_{103}+0,00201 \lambda_{113}\right]+ \\
& {\left[0 \lambda_{14}-0,00001 \lambda_{24}-0,00003 \lambda_{34}-\right.} \\
& 0,00006 \lambda_{44}-0,0001 \lambda_{54}- \\
& 0,00016 \lambda_{64}-0,00023 \lambda_{74}- \\
& 0,00031 \lambda_{84}-0,0004 \lambda_{94}- \\
& \left.0,00051 \lambda_{104}-0,00063 \lambda_{114}\right]+ \\
& {\left[0 \lambda_{15}+0 \lambda_{25}-0,00002 \lambda_{35}-\right.}
\end{aligned}
$$

$$
\begin{aligned}
& 0,00004 \lambda_{45}-0,00006 \lambda_{55}- \\
& 0,0001 \lambda_{65}-0,00014 \lambda_{75}- \\
& 0,00019 \lambda_{85}-0,00025 \lambda_{95}- \\
& \left.0,00032 \lambda_{105}-0,0004 \lambda_{115}\right]+ \\
& {\left[0 \lambda_{16}+0 \lambda_{26}-0,00001 \lambda_{36}-\right.} \\
& 0,00003 \lambda_{46}-0,00006 \lambda_{56}- \\
& 0,00009 \lambda_{66}-0,00013 \lambda_{76}- \\
& 0,00018 \lambda_{86}-0,00023 \lambda_{96}- \\
& 0,00029 \lambda_{106}-0,00036 \lambda_{116}
\end{aligned}
$$

dengan kendala,

$g_{1 j}\left(x_{k j}\right) \lambda_{k j}=\left[0 \lambda_{11}+0,1 \lambda_{21}+0,2 \lambda_{31}+\right.$ $0,3 \lambda_{41}+0,4 \lambda_{51}+0,5 \lambda_{61}+0,6 \lambda_{71}+$ $\left.0,7 \lambda_{81}+0,8 \lambda_{91}+0,9 \lambda_{101}+1 \lambda_{111}\right]+$ $\left[0 \lambda_{12}+0,1 \lambda_{22}+0,2 \lambda_{32}+0,3 \lambda_{42}+\right.$ $0,4 \lambda_{52}+0,5 \lambda_{62}+0,6 \lambda_{72}+0,7 \lambda_{82}+$ $\left.0,8 \lambda_{92}+0,9 \lambda_{102}+1 \lambda_{112}\right]+\left[0 \lambda_{13}+\right.$ $0,1 \lambda_{23}+0,2 \lambda_{33}+0,3 \lambda_{43}+0,4 \lambda_{53}+$ $0,5 \lambda_{63}+0,6 \lambda_{73}+0,7 \lambda_{83}+0,8 \lambda_{93}+$ $\left.0,9 \lambda_{103}+1 \lambda_{113}\right] \leq 1$

$g_{1 j}\left(x_{k j}\right) \lambda_{k j}=\left[0 \lambda_{11}+0,1 \lambda_{21}+0,2 \lambda_{31}+\right.$ $0,3 \lambda_{41}+0,4 \lambda_{51}+0,5 \lambda_{61}+0,6 \lambda_{71}+$ $\left.0,7 \lambda_{81}+0,8 \lambda_{91}+0,9 \lambda_{101}+1 \lambda_{111}\right]+$ $\left[0 \lambda_{12}+0,1 \lambda_{22}+0,2 \lambda_{32}+0,3 \lambda_{42}+\right.$ $0,4 \lambda_{52}+0,5 \lambda_{62}+0,6 \lambda_{72}+0,7 \lambda_{82}+$ $\left.0,8 \lambda_{92}+0,9 \lambda_{102}+1 \lambda_{112}\right]+\left[0 \lambda_{13}+\right.$ $0,1 \lambda_{23}+0,2 \lambda_{33}+0,3 \lambda_{43}+0,4 \lambda_{53}+$ $0,5 \lambda_{63}+0,6 \lambda_{73}+0,7 \lambda_{83}+0,8 \lambda_{93}+$ $\left.0,9 \lambda_{103}+1 \lambda_{113}\right] \leq 1$

$g_{2 j}\left(x_{k j}\right) \lambda_{k j}=\left[0 \lambda_{11}+0,1 \lambda_{21}+0,2 \lambda_{31}+\right.$ $0,3 \lambda_{41}+0,4 \lambda_{51}+0,5 \lambda_{61}+0,6 \lambda_{71}+$ $\left.0,7 \lambda_{81}+0,8 \lambda_{91}+0,9 \lambda_{101}+1 \lambda_{111}\right]+$ $\left[0 \lambda_{12}+0,1 \lambda_{22}+0,2 \lambda_{32}+0,3 \lambda_{42}+\right.$ $0,4 \lambda_{52}+0,5 \lambda_{62}+0,6 \lambda_{72}+0,7 \lambda_{82}+$ $\left.0,8 \lambda_{92}+0,9 \lambda_{102}+1 \lambda_{112}\right]+\left[-0 \lambda_{14}-\right.$ $0,1 \lambda_{24}-0,2 \lambda_{34}-0,3 \lambda_{44}-0,4 \lambda_{54}-$ $0,5 \lambda_{64}-0,6 \lambda_{74}-0,7 \lambda_{84}-0,8 \lambda_{94}-$ $\left.0,9 \lambda_{104}-1 \lambda_{114}\right]=0$

$g_{3 j}\left(x_{k j}\right) \lambda_{k j}=\left[0 \lambda_{11}+0,1 \lambda_{21}+0,2 \lambda_{31}+\right.$ $0,3 \lambda_{41}+0,4 \lambda_{51}+0,5 \lambda_{61}+0,6 \lambda_{71}+$ $\left.0,7 \lambda_{81}+0,8 \lambda_{91}+0,9 \lambda_{101}+1 \lambda_{111}\right]+$ $0 \lambda_{13}+0,1 \lambda_{23}+0,2 \lambda_{33}+0,3 \lambda_{43}+$ $0,4 \lambda_{53}+0,5 \lambda_{63}+0,6 \lambda_{73}+0,7 \lambda_{83}+$ $\left.0,8 \lambda_{93}+0,9 \lambda_{103}+1 \lambda_{113}\right]+\left[-0 \lambda_{15}-\right.$ 


$$
\begin{aligned}
& 0,1 \lambda_{25}-0,2 \lambda_{35}-0,3 \lambda_{45}-0,4 \lambda_{55}- \\
& 0,5 \lambda_{65}-0,6 \lambda_{75}-0,7 \lambda_{85}-0,8 \lambda_{95}- \\
& \left.0,9 \lambda_{105}-1 \lambda_{115}\right]=0 \\
& g_{4 j}\left(x_{k j}\right) \lambda_{k j}=\left[0 \lambda_{12}+0,1 \lambda_{22}+0,2 \lambda_{32}+\right. \\
& 0,3 \lambda_{42}+0,4 \lambda_{52}+0,5 \lambda_{62}+0,6 \lambda_{72}+ \\
& \left.0,7 \lambda_{82}+0,8 \lambda_{92}+0,9 \lambda_{102}+1 \lambda_{112}\right]+ \\
& {\left[0 \lambda_{13}+0,1 \lambda_{23}+0,2 \lambda_{33}+0,3 \lambda_{43}+\right.} \\
& 0,4 \lambda_{53}+0,5 \lambda_{63}+0,6 \lambda_{73}+0,7 \lambda_{83}+ \\
& \left.0,8 \lambda_{93}+0,9 \lambda_{103}+1 \lambda_{113}\right]+\left[-0 \lambda_{16}-\right. \\
& 0,1 \lambda_{26}-0,2 \lambda_{36}-0,3 \lambda_{46}-0,4 \lambda_{56}- \\
& 0,5 \lambda_{66}-0,6 \lambda_{76}-0,7 \lambda_{86}-0,8 \lambda_{96}- \\
& \left.0,9 \lambda_{106}-1 \lambda_{116}\right]=0 \\
& \lambda_{11}+\lambda_{21}+\lambda_{31}+\lambda_{41}+\lambda_{51}+\lambda_{61}+\lambda_{71}+ \\
& \lambda_{81}+\lambda_{91}+\lambda_{101}+\lambda_{111}=1, \\
& \lambda_{12}+\lambda_{22}+\lambda_{32}+\lambda_{42}+\lambda_{52}+\lambda_{62}+\lambda_{72}+ \\
& \lambda_{82}+\lambda_{92}+\lambda_{102}+\lambda_{112}=1, \\
& \lambda_{13}+\lambda_{23}+\lambda_{33}+\lambda_{43}+\lambda_{53}+\lambda_{63}+\lambda_{73}+ \\
& \lambda_{83}+\lambda_{93}+\lambda_{103}+\lambda_{113}=1, \\
& \lambda_{14}+\lambda_{24}+\lambda_{34}+\lambda_{44}+\lambda_{54}+\lambda_{64}+\lambda_{74}+ \\
& \lambda_{84}+\lambda_{94}+\lambda_{104}+\lambda_{114}=1, \\
& \lambda_{15}+\lambda_{25}+\lambda_{35}+\lambda_{45}+\lambda_{55}+\lambda_{65}+\lambda_{75}+ \\
& \lambda_{85}+\lambda_{95}+\lambda_{105}+\lambda_{115}=1, \\
& \lambda_{16}+\lambda_{26}+\lambda_{36}+\lambda_{46}+\lambda_{56}+\lambda_{66}+\lambda_{76}+ \\
& \lambda_{86}+\lambda_{96}+\lambda_{106}+\lambda_{116}=1, \\
& \quad \lambda_{v 1}, \lambda_{v 2}, \lambda_{v 3}, \lambda_{v 4}, \lambda_{v 6}, \lambda_{v 6} \geq 0, u n t u k \\
& \quad v=1,2, \ldots, 11 \\
& \quad \text { ven }
\end{aligned}
$$

5. Penyelesaian dengan metode simpleks

Fungsi linier yang terbentuk selanjutnya diselesaikan dengan metode simpleks untuk memperoleh masing-masing nilai $\lambda_{v j}$ dengan bantuan aplikasi POM for windows 3 , yaitu

$$
\begin{aligned}
& \lambda_{11}=\lambda_{21}=\lambda_{31}=\lambda_{51}=\lambda_{61}=\lambda_{71}= \\
& \lambda_{81}=\lambda_{91}=\lambda_{101}=\lambda_{111}=0, \lambda_{41}=1, \\
& \lambda_{12}=\lambda_{22}=\lambda_{32}=0, \lambda_{42}=1, \lambda_{52}= \\
& \lambda_{62}=\lambda_{72}=\lambda_{82}=\lambda_{92}=\lambda_{102}=\lambda_{112}=0, \\
& \lambda_{13}=\lambda_{23}=\lambda_{33}=0, \lambda_{43}=0,86, \lambda_{53}= \\
& \lambda_{63}=\lambda_{73}=\lambda_{83}=\lambda_{93}=\lambda_{103}=\lambda_{113}= \\
& 0,14, \\
& \lambda_{14}=\lambda_{24}=\lambda_{34}=\lambda_{44}=\lambda_{54}=\lambda_{64}= \\
& 0, \lambda_{74}=1, \lambda_{84}=\lambda_{94}=\lambda_{104}=\lambda_{114}=0, \\
& \lambda_{15}=\lambda_{25}=\lambda_{35}=\lambda_{45}=\lambda_{55}=\lambda_{65}= \\
& \lambda_{75}=0, \lambda_{85}=1, \lambda_{95}=\lambda_{105}=\lambda_{115}=0, \\
& \lambda_{16}=\lambda_{26}=\lambda_{36}=\lambda_{46}=\lambda_{56}=\lambda_{66}= \\
& 0, \lambda_{76}=0,5, \lambda_{86}=0, \lambda_{96}=0,5, \lambda_{106}= \\
& \lambda_{116}=0 .
\end{aligned}
$$

Setiap nilai $\lambda_{v j}$ selanjutnya disubstitusikan ke persamaan berikut

$$
\begin{gathered}
x_{1}=0 \lambda_{11}+0,1 \lambda_{21}+0,2 \lambda_{31}+0,3 \lambda_{41}+ \\
0,4 \lambda_{51}+0,5 \lambda_{61}+0,6 \lambda_{71}+ \\
0,7 \lambda_{81}+0,8 \lambda_{91}+0,9 \lambda_{101}+1 \lambda_{111}, \\
x_{2}=0 \lambda_{12}+0,1 \lambda_{22}+0,2 \lambda_{32}+0,3 \lambda_{42}+ \\
0,4 \lambda_{52}+0,5 \lambda_{62}+0,6 \lambda_{72}+ \\
0,7 \lambda_{82}+0,8 \lambda_{92}+0,9 \lambda_{102}+1 \lambda_{112}, \\
x_{3}=0 \lambda_{13}+0,1 \lambda_{23}+0,2 \lambda_{33}+0,3 \lambda_{43}+ \\
0,4 \lambda_{53}+0,5 \lambda_{63}+0,6 \lambda_{73}+ \\
0,7 \lambda_{83}+0,8 \lambda_{93}+0,9 \lambda_{103}+1 \lambda_{113}, \\
x_{4}=0 \lambda_{14}+0,1 \lambda_{24}+0,2 \lambda_{34}+0,3 \lambda_{44}+ \\
0,4 \lambda_{54}+0,5 \lambda_{64}+0,6 \lambda_{74}+ \\
0,7 \lambda_{84}+0,8 \lambda_{94}+0,9 \lambda_{104}+1 \lambda_{114}, \\
x_{5}=0 \lambda_{15}+0,1 \lambda_{25}+0,2 \lambda_{35}+0,3 \lambda_{45}+ \\
0,4 \lambda_{55}+0,5 \lambda_{65}+0,6 \lambda_{75}+ \\
0,7 \lambda_{85}+0,8 \lambda_{95}+0,9 \lambda_{105}+1 \lambda_{115}, \\
x_{6}=0 \lambda_{16}+0,1 \lambda_{26}+0,2 \lambda_{36}+0,3 \lambda_{46}+ \\
0,4 \lambda_{56}+0,5 \lambda_{66}+0,6 \lambda_{76}+ \\
0,7 \lambda_{86}+0,8 \lambda_{96}+0,9 \lambda_{106}+1 \lambda_{11} .
\end{gathered}
$$

Diperoleh proporsi dana, yaitu

$x_{1}=0,3, \quad x_{2}=0,3, \quad x_{3}=0,4, \quad x_{4}=0,6$, $x_{5}=0,7$, dan $x_{6}=0,7$.

Selanjutnya nilai $x_{j}$ tersebut disubstitusikan ke persamaan (5), sehingga diperoleh keuntungan maksimum berdasarkan perhitungan menggunakan separable programming yaitu 0,001677 .

\section{Penyelesaian Model Menggunakan Metode Quadratic programming}

Langkah-langkah penyelesaian pemrograman kuadratik metode wolfe sebagai berikut

1. Mengidentifikasi permasalahan kuadratik Fungsi tujuan dan kendala dalam bentuk permasalahan kuadratik yaitu

$$
\mathbf{z}=\mathbf{C X}+\mathbf{X}^{\mathbf{T}} \mathbf{D X}
$$

dengan,

$$
\begin{aligned}
\mathbf{X} & =\left[\begin{array}{lll}
x_{1} & x_{2} & x_{3}
\end{array}\right]^{T}, \\
\mathbf{C} & =\left[\begin{array}{lll}
0,00257 & 0,00258 & 0,00202
\end{array}\right] \\
\mathbf{D} & =\left[\begin{array}{ccc}
-0,0015 & -0,00063 & -0,0004 \\
-0,0006 & -0,0014 & -0,00036 \\
-0,0004 & -0,00036 & -0,0008
\end{array}\right] \\
\mathbf{A} & =\left[\begin{array}{lll}
1 & 1 & 1
\end{array}\right], \\
\mathbf{b} & =\left[\begin{array}{lll}
1
\end{array}\right]
\end{aligned}
$$$$
\text { dengan kendala, }
$$$$
\boldsymbol{G}(\boldsymbol{X})=\left[\begin{array}{lll}
\mathbf{1} & \mathbf{1} & \mathbf{1}
\end{array}\right]\left[\begin{array}{l}
x_{1} \\
x_{2} \\
x_{3}
\end{array}\right]-[1] \leq \mathbf{0}
$$ 


$$
-\left[\begin{array}{l}
x_{1} \\
x_{2} \\
x_{3}
\end{array}\right] \leq \mathbf{0}
$$

2. Membentuk model linier dengan syarat Kuhn Tucker

Setelah diperoleh bentuk umum dari permasalahan kuadratik, maka selanjutnya adalah mentransformasikan bentuk kuadratik tersebut menjadi fungsi linier menggunakan syarat Kuhn Tucker.

Berdasarkan penerapan syarat Kuhn Tucker pada model (5) dan (6), maka diperoleh fungsi linier dan kendala baru sebagai berikut

$$
\begin{aligned}
z= & 0,00496 x_{1}+0,0048 x_{2}+ \\
& 0,0031 x_{3}+3 \lambda_{1}-\mu_{1}-\mu_{2}- \\
& \mu_{3}-0,0072
\end{aligned}
$$

dengan kendala,

$$
\begin{aligned}
& 0,00292 x_{1}+0,00125 x_{2}+ \\
& 0,000792 x_{3}+\lambda_{1}-\mu_{1}=0,00257 \\
& 0,00125 x_{1}+0,00282 x_{2}+ \\
& 0,000728 x_{3}+\lambda_{1}-\mu_{2}=0,00258 \\
& 0,000792 x_{1}+0,000728 x_{2}+ \\
& 0,00154 x_{3}+\lambda_{1}-\mu_{3}=0,00202 \\
& x_{1}+x_{2}+x_{3}+S_{1}=1
\end{aligned}
$$

3. Mencari solusi optimal dengan simpleks wolfe

Setelah diperoleh fungsi tujuan dan kendala yang baru, yaitu persamaan (12) dan (13) selanjutnya dilakukan perhitungan untuk memperoleh solusi optimalnya.

Diperoleh tabel optimum simpleks metode wolfe sebagai berikut

Tabel 4. Nilai Optimum Simpleks Metode Wolfe

\begin{tabular}{|c|c|c|c|c|c|c|c|c|c|c|c|c|}
\hline Basic & $x_{1}$ & $x_{2}$ & $x_{3}$ & $\lambda_{1}$ & $\mu_{1}$ & $\mu_{2}$ & $\mu_{3}$ & $R_{1}$ & $R_{2}$ & $R_{3}$ & $S_{1}$ & Solusi \\
\hline$r$ & 0 & 0 & 0 & 0 & 0 & 0 & 0 & 1 & -1 & -1 & -1 & 0 \\
\hline$x_{1}$ & 1 & 0 & 0 & 0 & $-430,9$ & 188,5 & 242,5 & 0 & 430,9 & $-188,5$ & $-242,3$ & 0,30 \\
\hline$\lambda_{1}$ & 0 & 0 & 0 & 1 & $-0,17$ & $-0,2$ & $-0,6$ & 0 & 0,2 & 0,2 & 0,6 & 0 \\
\hline$x_{3}$ & 0 & 0 & 1 & 0 & 242,5 & 238,3 & $-480,8$ & 0 & $-242,5$ & $-238,3$ & 481,4 & 0,36 \\
\hline$x_{2}$ & 0 & 1 & 0 & 0 & 188,5 & $-426,8$ & 238,3 & 0 & $-188,5$ & 426,8 & -238 & 0,34 \\
\hline
\end{tabular}

Berdasarkan Tabel 4, diperoleh bahwa nilai $x_{1}=0,3, \quad x_{2}=0,34 \quad$ dan $\quad x_{3}=0,36$. Selanjutnya, untuk memperoleh nilai optimum maka nilai $x_{1}, x_{2}$ dan $x_{3}$ disubstitusikan ke persamaan (5) sehingga diperoleh keuntungan maksimum berdasarkan perhitungan menggunakan metode quadratic programming adalah 0,001679 , dengan proporsi dana yang diinvestasikan ke saham BMRI sebesar $30 \%$, GGRM sebesar $34 \%$ dan ICBP sebesar $36 \%$.

\section{KESIMPULAN DAN SARAN}

\section{Kesimpulan}

1. Perhitungan menggunakan metode separable programming dan quadratic programming memiliki nilai optimum yang relatif sama.

2. Penyelesaian model nonlinier portofolio Markowitz dari kombinasi proporsi tiga saham menggunakan metode quadratic programming lebih efektif dan efisien.

\section{Saran}

Bagi pembaca yang ingin menyelesaikan permasalahan pemrograman nonlinier yang memiliki model fungsi tujuan dan kendala seperti model portofolio Markowitz dapat menggunakan metode quadratic programming untuk memperoleh solusi optimalnya, karena penyelesaian menggunakan metode ini memiliki langkah penyelesaian yang lebih singkat dibandingkan dengan metode separable dengan hasil optimal dan dapat dilakukan tanpa bantuan aplikasi tambahan. Bagi pembaca atau peneliti yang tertarik untuk mengakaji lebih dalam tentang perbandingan penyelesaian pemrograman nonlinier dapat mengkaji metode lainnya seperti Karush Kuhn Tucker, chanceconstrained programming, linier combination method dan lainnya.

\section{DAFTAR PUSTAKA}

Hillier, F. S., \& Lieberman, G. J. (2005). Introduction To Operation Research, Eighth Edition. New York: The McGrawHill Companies, Inc.

Insani, S. N. (2017). Optimasi Tanaman Pangan di Kota Magelang dengan Pemrograman Kuadratik dan Metode Pinalti Eksterior. 
Jurnal Matematika Vol. 6 No 2.

Mulyono, S. (1989). Program Non Linier. Ekonomi dan Keuangan Indonesia, Vol 37, no 2, 219 - 244.
Taha, H. A. (2007). Operations Research An Introduction. New Jersey: Pearson Pentrice Hall. 